\title{
Organometallic Uranyl Complexes Featuring a Carbodicarbene Ligand
}

Arnab K. Maity, ${ }^{\dagger}$ Robert J. Ward, ${ }^{\S}$ D.M. Ramitha Y.P. Rupasinghe, ${ }^{\dagger}$ Matthias Zeller, ${ }^{\dagger}$ Justin R. Walensky, ${ }^{\S}$ and Suzanne C. Bart ${ }^{*}$

${ }^{\dagger}$ H. C. Brown Laboratory, Department of Chemistry, Purdue University, West Lafayette, Indiana 47907, United States

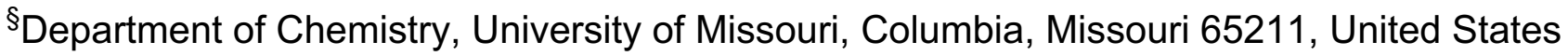

Correspondence: sbart@purdue.edu

\section{Supporting Information}

1. Experimental Section $\quad S 2$

2. NMR Spectra $\quad$ S5

$\begin{array}{ll}\text { 3. IR Spectra } & \mathrm{S} 10\end{array}$

4. Raman Data $\quad \mathrm{S} 12$

5. X-Ray Data $\quad$ S14

6. References $\quad$ S16 


\section{Experimental Section}

General Considerations. All air- and moisture sensitive manipulations were performed using standard Schlenk techniques or in an MBraun inert atmosphere drybox filled with purified nitrogen. Solvents for sensitive manipulations were dried and deoxygenated using literature procedures with a Seca solvent purification system. ${ }^{1}$ THF- $d_{8}$ was purchased from Cambridge Isotope Laboratories, dried over sodium prior to use. Water $\left({ }^{18} \mathrm{O}, 97 \%\right)$ was purchased from Cambridge Isotope Laboratories and used as received. Uranyl triflate $\mathrm{UO}_{2}(\mathrm{OTf})_{2}(\mathrm{THF})_{3},{ }^{2}$ uranyl dichloride $\left[\mathrm{UO}_{2} \mathrm{Cl}_{2}(\mathrm{THF})_{2}\right],{ }^{3}{ }^{18} \mathrm{O}$-labeled uranyl dichloride $\left[\mathrm{U}^{18} \mathrm{O}_{2} \mathrm{Cl}_{2}(\mathrm{THF})_{2}\right]_{2}{ }^{4}{ }_{1,2-}$ diphenoxy-3,5-bis(2,6-dimethylphenyl)pyrazolin-4-ylidene (CDC'), ${ }^{5}$ were prepared according to literature procedures. ${ }^{18} \mathrm{O}$-labeled uranyl triflate $\mathrm{U}^{18} \mathrm{O}_{2}(\mathrm{OTf})_{2}(\mathrm{THF})_{3}$ was synthesized from $\left[\mathrm{U}^{18} \mathrm{O}_{2} \mathrm{Cl}_{2}(\mathrm{THF})_{2}\right]_{2}$ and AgOTf according to the literature procedure. ${ }^{6}{ }^{1} \mathrm{H},{ }^{19} \mathrm{~F}\left\{{ }^{1} \mathrm{H}\right\}$ and ${ }^{13} \mathrm{C}\left\{{ }^{1} \mathrm{H}\right\}$ NMR spectra were collected at room temperature on a Bruker AV-111-400-HD and Bruker Avance-III-800 NMR spectrometer. ${ }^{1} \mathrm{H},{ }^{19} \mathrm{~F}\{1 \mathrm{H}\}$ and ${ }^{13} \mathrm{C}\left\{{ }^{1} \mathrm{H}\right\}$ NMR spectra are reported in parts per million relative to tetramethylsilane, using the residual solvent resonances as an internal standard. Solid state IR data were collected on a Thermo Nicolet 6700 spectrophotometer. Raman spectra were recorded on a Anton Paar Cora 5700 Fiber Dualband system equipped with a f/2 Transmission Volume Phase Grating, fiber optic probe, and 2048 px CCD detector array for $785 \mathrm{~nm}$ wavelengths and $256 \mathrm{px}$ InGaAs detector array for $1064 \mathrm{~nm}$ wavelengths. The $785 \mathrm{~nm}$ excitation source was used to obtain the spectra at a 100 $\mathrm{cm}^{-1}$ to $2300 \mathrm{~cm}^{-1}$ spectral range with a resolution of $6 \mathrm{~cm}^{-1}$ to $9 \mathrm{~cm}^{-1}$. Spectra of solid samples were acquired using sixteen $4000 \mathrm{~ms}$ exposures at $400 \mathrm{~mW}$ laser power after determination of the optimal signal to noise ratio and maximum power possible before sample damage. Samples were prepared inside a nitrogen-filled glovebox by sealing pure microcrystalline solid samples between two microscope slides and subsequent removal from glovebox for acquisition. Elemental Analyses were performed by Midwest Microlab (Indianapolis, IN).

Single X-Ray Crystallography. Single crystal for complex 1-OTf was coated with a trace of mineral oil and quickly transferred to the goniometer head of a Bruker Quest diffractometer with a fixed chi angle, a sealed tube fine focus X-ray tube, single crystal curved graphite incident beam monochromator, a Photon 100 CMOS area detector and an Oxford Cryosystems low temperature device. Examination and data collection were performed with Mo $\mathrm{K} \alpha$ radiation $(\lambda$ $=0.71073 \AA$ ) at $100 \mathrm{~K}$. Data were collected, reflections were indexed and processed, and the files scaled and corrected for absorption using APEX3 (Bruker, 2016) and Sadabs (Krause et al., 2015). The space group was assigned and the structure was solved by direct methods using XPREP and XS within the SHELXTL suite of programs (Bruker, 2003; Sheldrick, 2008) and refined by full matrix least squares against $\mathrm{F}^{2}$ with all reflections using Shelx|2018 (Sheldrick, 2015, 2018) using the graphical interface Shelxle (Hübschle, 2011). If not specified otherwise $\mathrm{H}$ atoms attached to carbon and nitrogen atoms and hydroxyl hydrogens were positioned geometrically and constrained to ride on their parent atoms, with carbon hydrogen bond distances of $0.95 \AA$ for and aromatic $\mathrm{CH}$, and $0.98 \AA$ for $\mathrm{CH}_{3}$ moieties, respectively. Methyl $\mathrm{H}$ atoms were allowed to rotate but not to tip to best fit the experimental electron density. $U_{\text {iso }}(H)$ values were set to a multiple of $\mathrm{U}_{\mathrm{eq}}(\mathrm{C})$ with 1.5 for $\mathrm{CH}_{3}$, and 1.2 for $\mathrm{CH}$ units, respectively. 
Additional data collection and refinement details, including handling of highly disordered solvate molecules, can be found in section 4 below. Complete crystallographic data, in CIF format, have been deposited with the Cambridge Crystallographic Data Centre. CCDC 1969836 contains the supplementary crystallographic data for this paper. These data can be obtained free of charge from The Cambridge Crystallographic Data Centre via www.ccdc.cam.ac.uk/data request/cif.

Computational Details. The electronic structure of 1-OTf was examined using the Gaussian 16 suite of software ${ }^{7}$ at the B3PW91-GD3BJ (Becke-330 exchange ${ }^{8}$ and Perdew and Wang ${ }^{9}$ correlation functional which includes dispersion effects ${ }^{10}$ ) level. The structure was truncated by replacing phenyl substituent on each nitrogen with hydrogen atoms, and stationary points were determined to be global minima using analytical frequency calculations. The uranium was treated with the Stuttgart/Dresden triple- $\zeta$ quality basis set $^{11-13}$ and the corresponding effective core potential (ECP). The Pople double- $\zeta$ quality basis set, $6-31+G^{*},{ }^{14}$, ${ }^{15}$ was used for all remaining atoms. Bader's Atoms in Molecules (AIM) analysis was performed using Multiwfn. ${ }^{16}$ The supplemental file am_1_50a_sq.xyz contains the computed Cartesian coordinates of all of the molecules reported in this study. The file may be opened as a text file to read the coordinates, or opened directly by a molecular modeling program such as Mercury (version 3.3 or later, http://www.ccdc.cam.ac.uk/pages/Home.aspx) for visualization and analysis.

Synthesis of $(C D C)_{2} \mathrm{UO}_{2}(\mathrm{OTf})_{2}$ (1-OTf). A 20-mL scintillation vial was charged with $\mathrm{UO}_{2}(\mathrm{OTf})_{2}(\mathrm{THF})_{3}(200 \mathrm{mg}, 0.25 \mathrm{mmol})$, THF $(5 \mathrm{~mL})$, and a stir bar and was stirred for $15 \mathrm{~min}$ until dissolved to form an off-white colored solution. A separate $20-\mathrm{mL}$ scintillation vial was charged with freshly prepared CDC' ( $255 \mathrm{mg}, 0.55 \mathrm{mmol}, 2.2$ equiv), dissolved in diethyl ether $(5 \mathrm{~mL})$, and added dropwise to the stirring solution of $\mathrm{UO}_{2}(\mathrm{OTf})_{2}(\mathrm{THF})_{3}$. The pale yellow solution was stirred for $3 \mathrm{~h}$ and filtered through a glass fiber pad. The reaction mixture was then concentrated under reduced pressure (ca. $3 \mathrm{~mL}$ ). Diethyl ether $(10 \mathrm{~mL})$ was layered and the solution was stored at $-35{ }^{\circ} \mathrm{C}$ overnight to afford a pale yellow microcrystalline solid. The solvent was decanted, and the solid was washed thoroughly with diethyl ether $(3 \times 5 \mathrm{~mL})$ and dried under reduced pressure to afford 1-OTf $\left(350 \mathrm{mg}, 0.23 \mathrm{mmol}, 93 \%\right.$ yield). ${ }^{1} \mathrm{H}$ NMR (400 $\left.\mathrm{MHz}, 298 \mathrm{~K}, \mathrm{THF}-d_{8}\right): \delta=2.16(\mathrm{~s}, 24 \mathrm{H}), 6.54-6.64(\mathrm{~m}, 12 \mathrm{H}), 7.03-7.14(\mathrm{~m}, 20 \mathrm{H}) .{ }^{13} \mathrm{C}\left\{{ }^{1} \mathrm{H}\right\}$ NMR $\left(200 \mathrm{MHz}, 298 \mathrm{~K}, \mathrm{THF}-d_{8}\right): \delta 17.9\left(\mathrm{CH}_{3}\right), 125.7(\mathrm{CCC}), 129.3\left(\mathrm{CH}^{\mathrm{Ar}}\right), 129.4\left(\mathrm{CH}^{\mathrm{Ar}}\right), 130.4$ $\left(\mathrm{CH}^{\mathrm{Ar}}\right), 130.7\left(\mathrm{CH}^{\mathrm{Ar}}\right), 130.9\left(\mathrm{CH}^{\mathrm{Ar}}\right), 134.7\left(\mathrm{CCH}_{3}\right), 154.0\left(\mathrm{NC}^{\mathrm{Ar}}\right), 171.7\left(\mathrm{OC}^{\mathrm{Ar}}\right), 186.5(\mathrm{NCO}) \cdot{ }^{19} \mathrm{~F}$ $\operatorname{NMR}\left(400 \mathrm{MHz}, 298 \mathrm{~K}, \mathrm{THF}-d_{8}\right): \delta-79$. Anal. Calcd. for $1\left(\mathrm{C}_{64} \mathrm{H}_{56} \mathrm{~F}_{6} \mathrm{~N}_{4} \mathrm{O}_{12} \mathrm{~S}_{2} \mathrm{U}\right): \mathrm{C} 51.61, \mathrm{H}$ 3.79, N 3.76; found: C 51.52, H 3.88, N 3.66.

Synthesis of $(\mathrm{CDC})_{2} \mathrm{UO}_{2} \mathrm{Cl}_{2}(1-\mathrm{Cl})$. A $20-\mathrm{mL}$ scintillation vial was charged with $\left[\mathrm{UO}_{2} \mathrm{Cl}_{2}(\mathrm{THF})_{2}\right]_{2}(100 \mathrm{mg}, 0.10 \mathrm{mmol})$, THF $(5 \mathrm{~mL})$, and a stir bar and was stirred for $15 \mathrm{~min}$ to make a solution. A separate $20-\mathrm{mL}$ scintillation vial was charged with freshly prepared CDC' (194 mg, $0.42 \mathrm{mmol}, 4.2$ equiv), dissolved in THF ( $5 \mathrm{~mL}$ ), and added dropwise to the 
stirring solution of $\left[\mathrm{UO}_{2} \mathrm{Cl}_{2}(\mathrm{THF})_{2}\right]_{2}$. An immediate precipitation of a pale yellow powder was observed. The suspension was stirred for $3 \mathrm{~h}$ and kept at $-35^{\circ} \mathrm{C}$ overnight for the solid to settle to the bottom of the vial. The solution was decanted and the solid was washed thoroughly with diethyl ether $(3 \times 5 \mathrm{~mL})$ and dried under reduced pressure to afford 2 (230 $\mathrm{mg}, 0.17 \mathrm{mmol}, 86 \%$ yield). Complex 1-Cl immediately decomposes in $\mathrm{CH}_{2} \mathrm{Cl}_{2}, \mathrm{CHCl}_{3}$, and pyridine. Anal. Calcd. for 1-Cl*THF $\left(\mathrm{C}_{66} \mathrm{H}_{64} \mathrm{Cl}_{2} \mathrm{~N}_{4} \mathrm{O}_{7} \mathrm{U}\right)$ : C 59.42, $\mathrm{H} 4.84, \mathrm{~N} 4.20$; found: $\mathrm{C}$ 59.56, H 5.04, N 3.77. ${ }^{1} \mathrm{H}$ NMR (400 MHz, $\left.298 \mathrm{~K}, \mathrm{ACN}-d_{3}\right): \delta=2.20(\mathrm{~s}, 24 \mathrm{H}), 7.14(\mathrm{~m}, 12 \mathrm{H})$, $7.56(\mathrm{~m}, 12 \mathrm{H}), 7.71(\mathrm{~m}, 8 \mathrm{H}) .{ }^{13} \mathrm{C}\left\{{ }^{1} \mathrm{H}\right\} \mathrm{NMR}\left(200 \mathrm{MHz}, 298 \mathrm{~K}, \mathrm{ACN}-d_{3}\right): 16.1\left(\mathrm{CH}_{3}\right), 128.7$ (CCC), 130.1 $\left(\mathrm{CH}^{\mathrm{Ar}}\right), 130.5\left(\mathrm{CH}^{\mathrm{Ar}}\right), 130.7\left(\mathrm{CH}^{\mathrm{Ar}}\right), 130.8\left(\mathrm{CH}^{\mathrm{Ar}}\right), 131.1\left(\mathrm{CH}^{\mathrm{Ar}}\right), 133.0\left(\mathrm{CCH}_{3}\right)$, $150.9\left(\mathrm{NC}^{\mathrm{Ar}}\right), 158.6\left(\mathrm{OC}^{\mathrm{Ar}}\right)$. NCO peak is not visible for ${ }^{13} \mathrm{C}$ NMR due to partial solubility in acetonnitrile- $d_{3}$. 


\section{NMR Spectra}

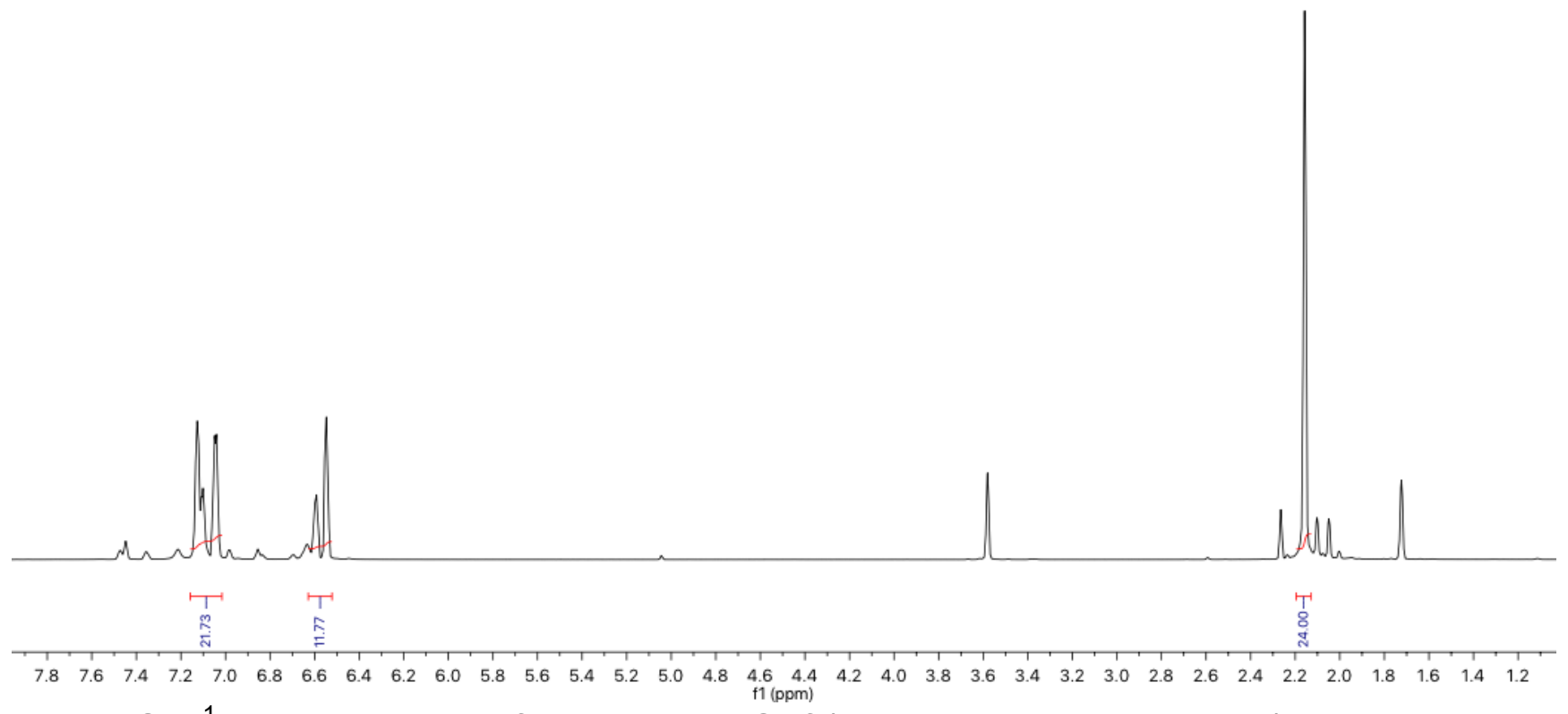

Figure S1. 'H NMR spectrum for complex 1-OTf (THF- $d_{8}$, room temperature). 


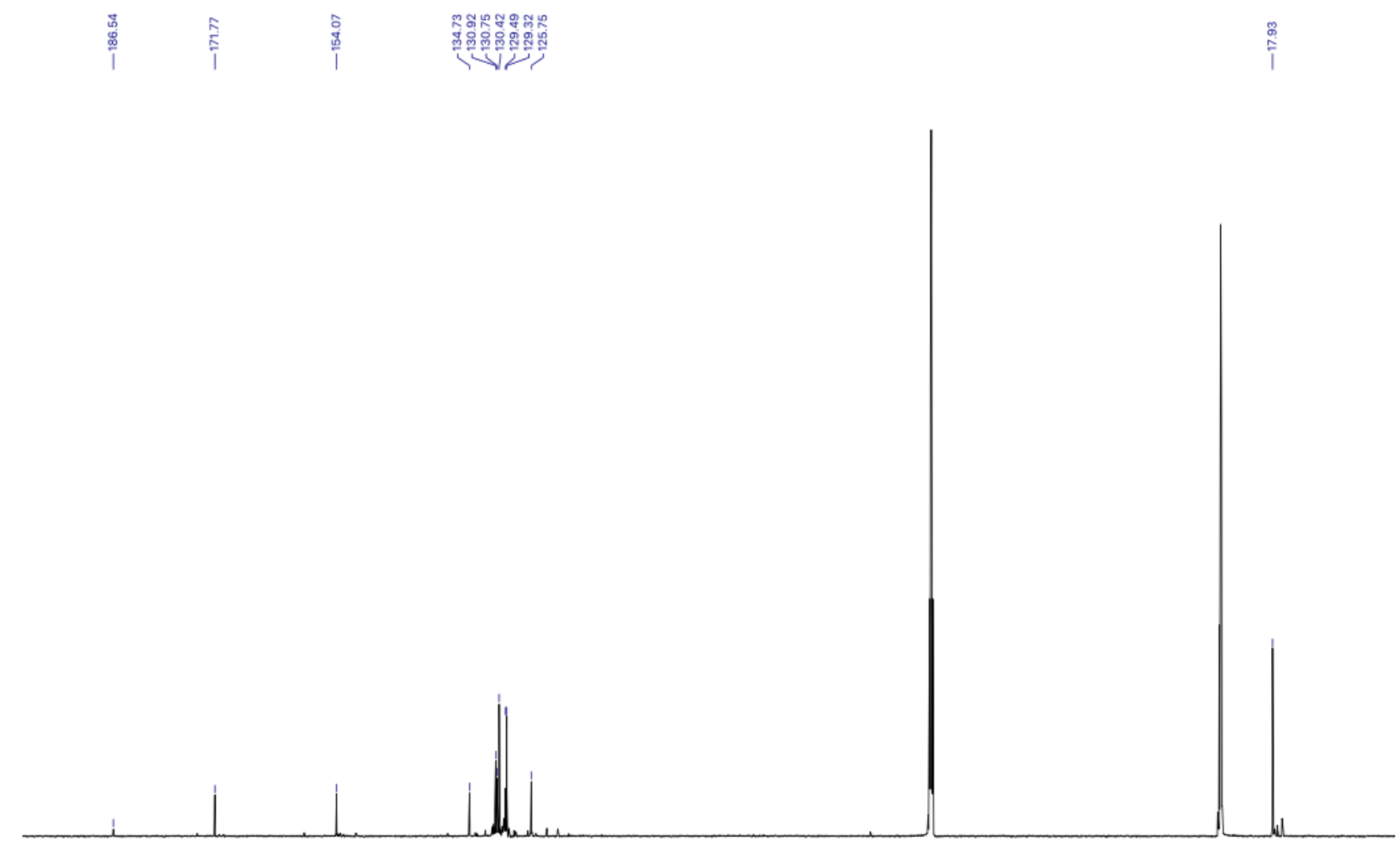

190

$\begin{array}{llll}180 & 170 \quad 160 & 150\end{array}$

$140 \quad 130 \quad 120$

$110 \quad 100$

Figure S2. ${ }^{13} \mathrm{C}$ NMR spectrum for complex 1-OTf (THF- $d_{8}$, room temperature). 


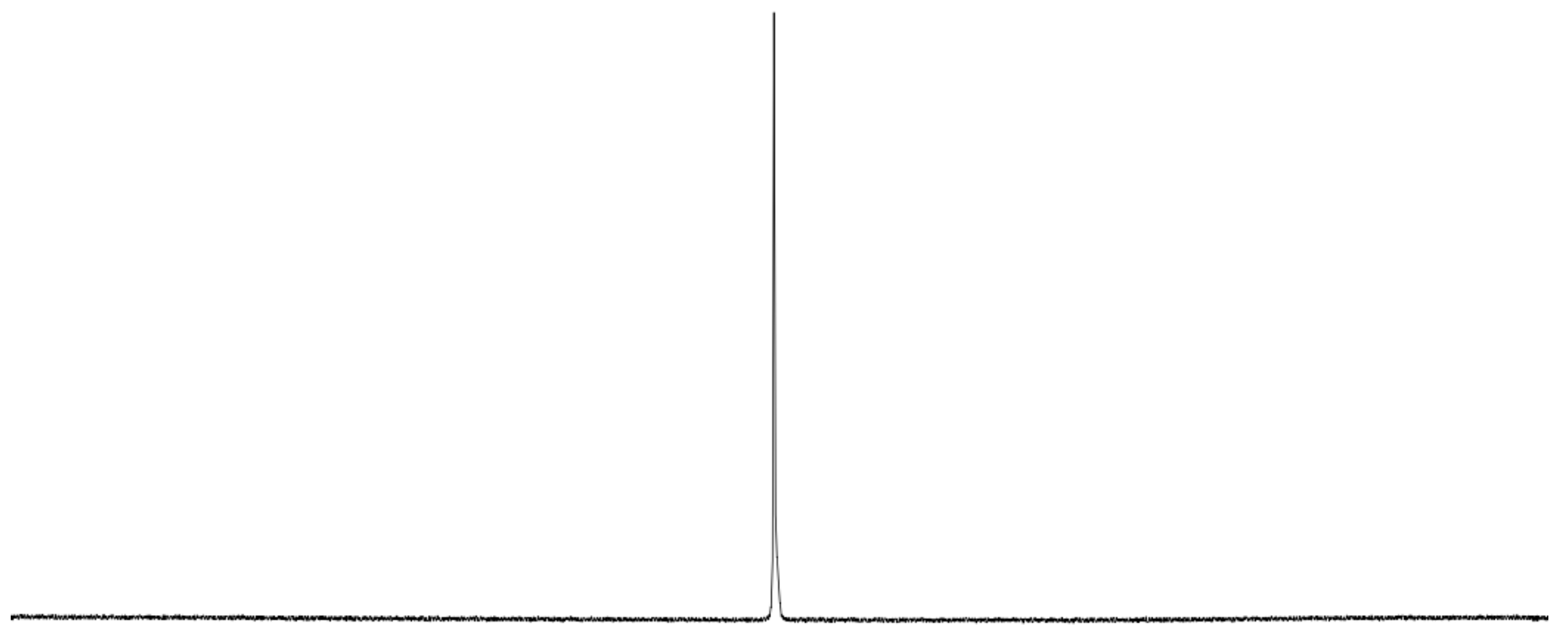

$\begin{array}{llllllllllllllllllllllllllllllllllllll}10 & -15 & -20 & -25 & -30 & -35 & -40 & -45 & -50 & -55 & -60 & -65 & -70 & -75 & -80 & -85 & -90 & -95 & -100 & -105 & -110 & -115 & -120 & -125 & -130 & -135 & -140 & -145\end{array}$ Figure S3. ${ }^{19} \mathrm{~F}$ NMR spectrum for complex 1-OTf (THF- $d_{8}$, room temperature). 


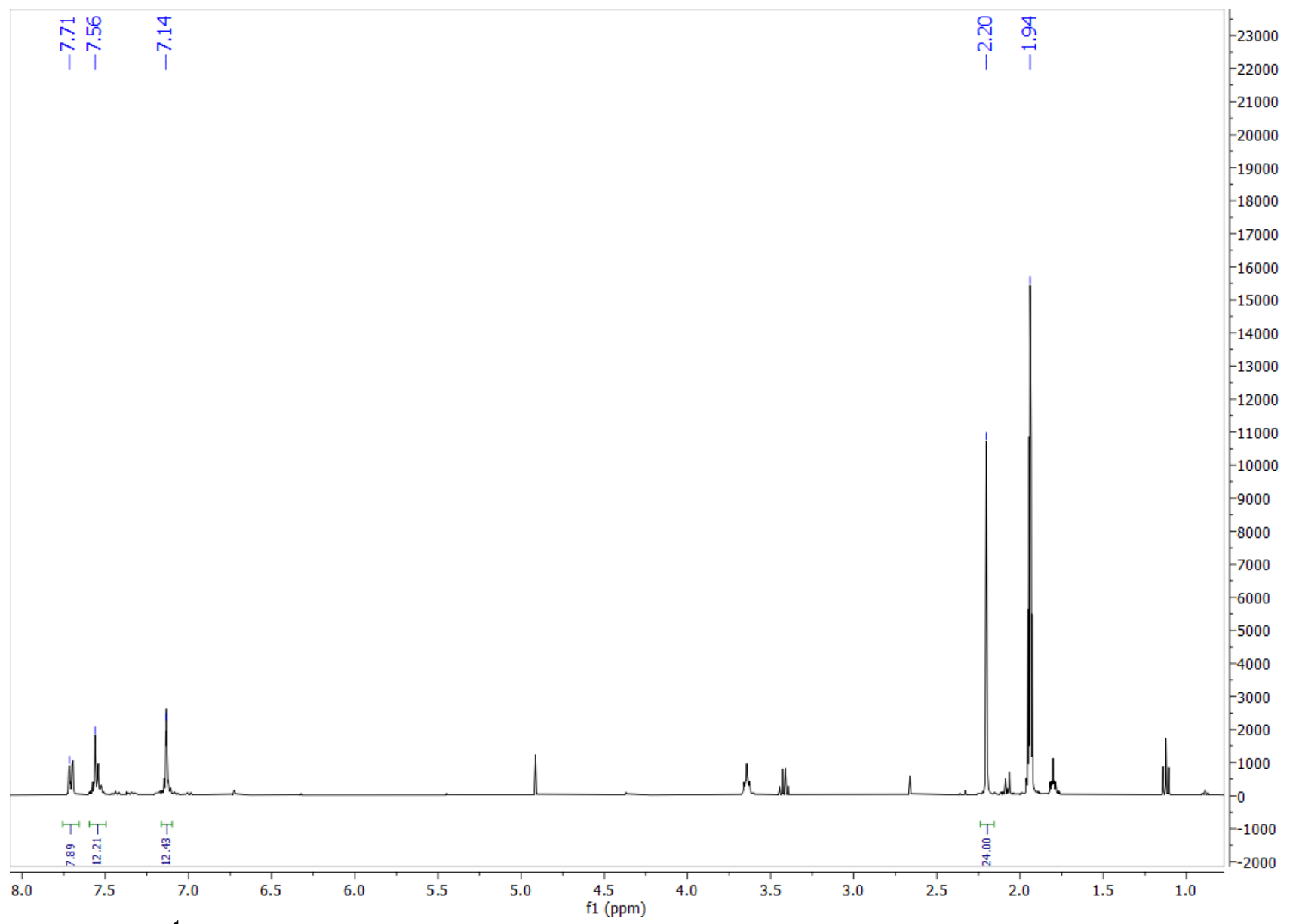

Figure S4. ${ }^{1} \mathrm{H}$ NMR spectrum for complex 1-CI (Acetonitrile- $d_{3}$, room temperature). 


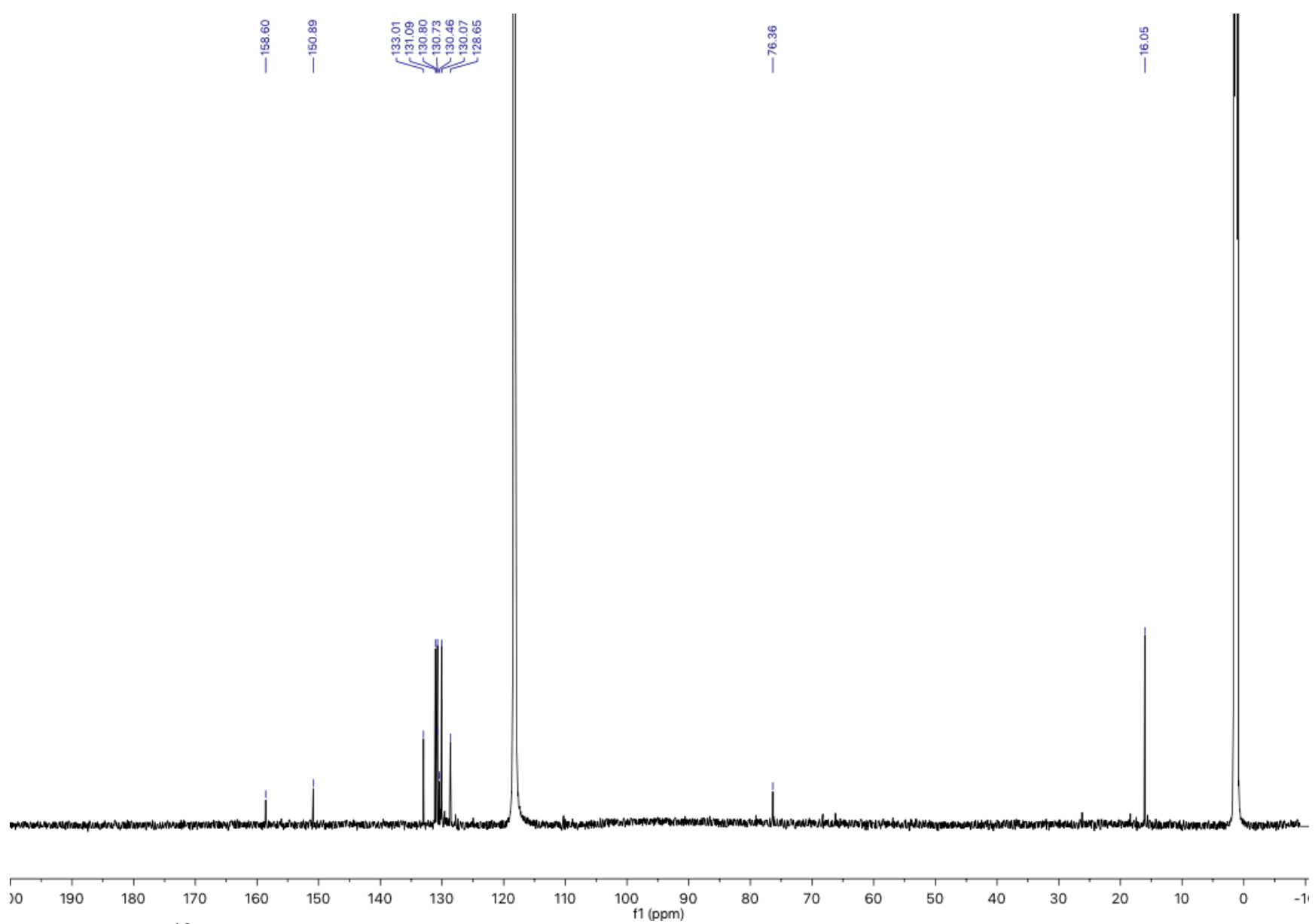

Figure S5. ${ }^{13} \mathrm{C}$ NMR spectrum for complex 1-Cl (Acetonitrile- $d_{3}$, room temperature). 


\section{Infrared Spectra}

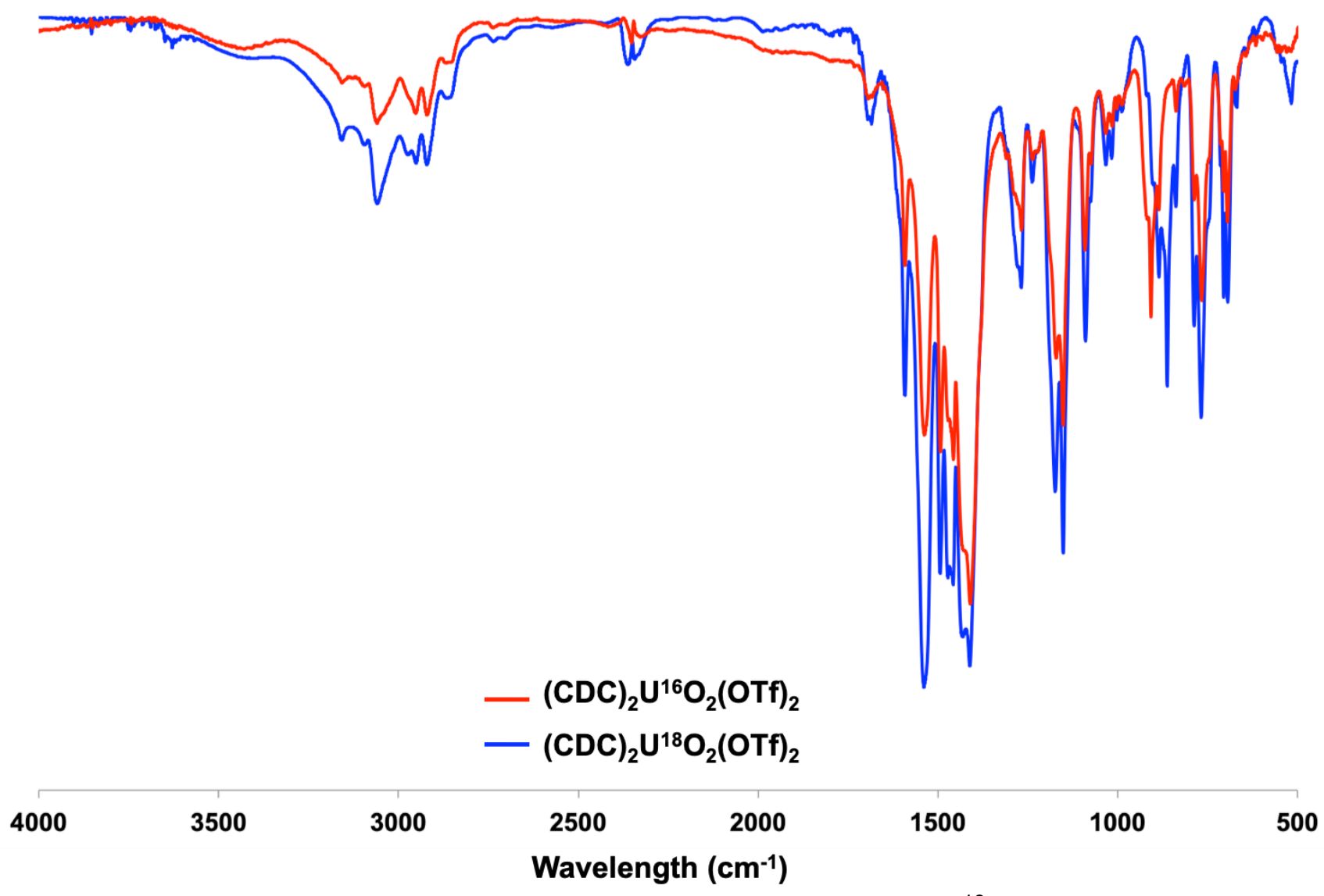

Figure S6. Overlay of solid state IR spectra for complex 1-OTf and ${ }^{18} \mathrm{O}$-labeled complex 1OTf- ${ }^{18} \mathrm{O}$. 


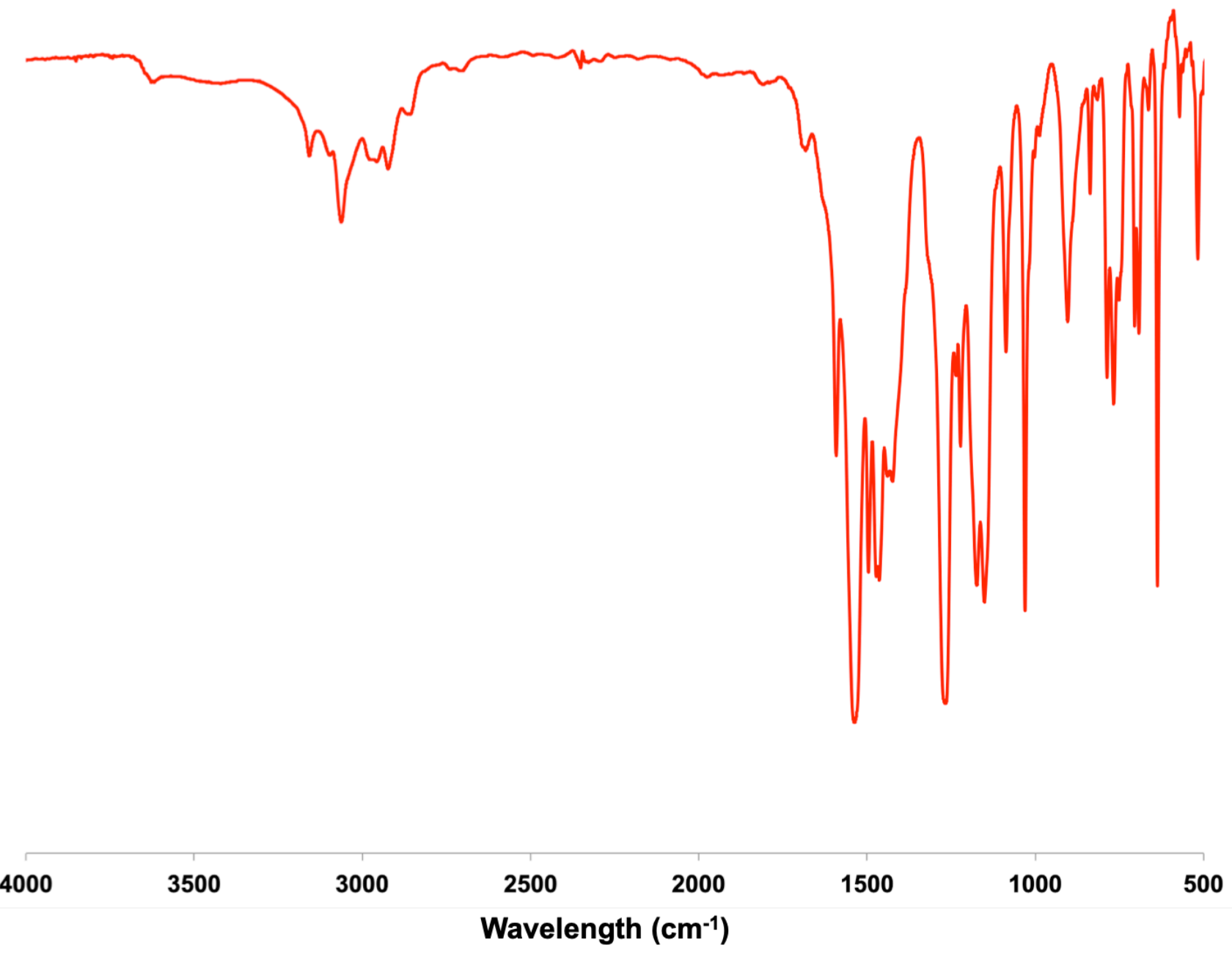

Figure S7. Solid state IR spectrum for complex 1-Cl. 


\section{Raman Data}

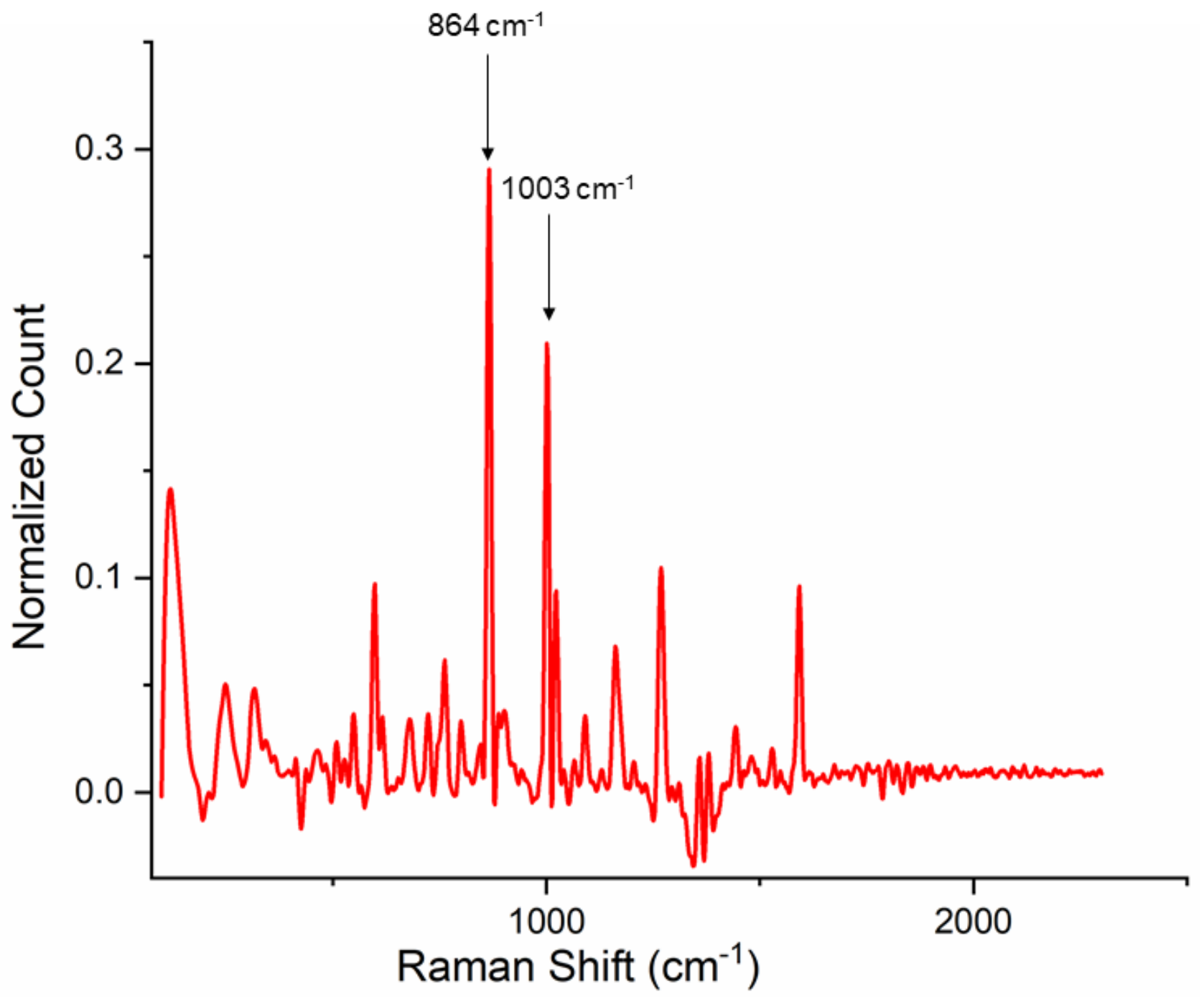

Figure S8. Solid state Raman spectrum for complex 1-OTf. 


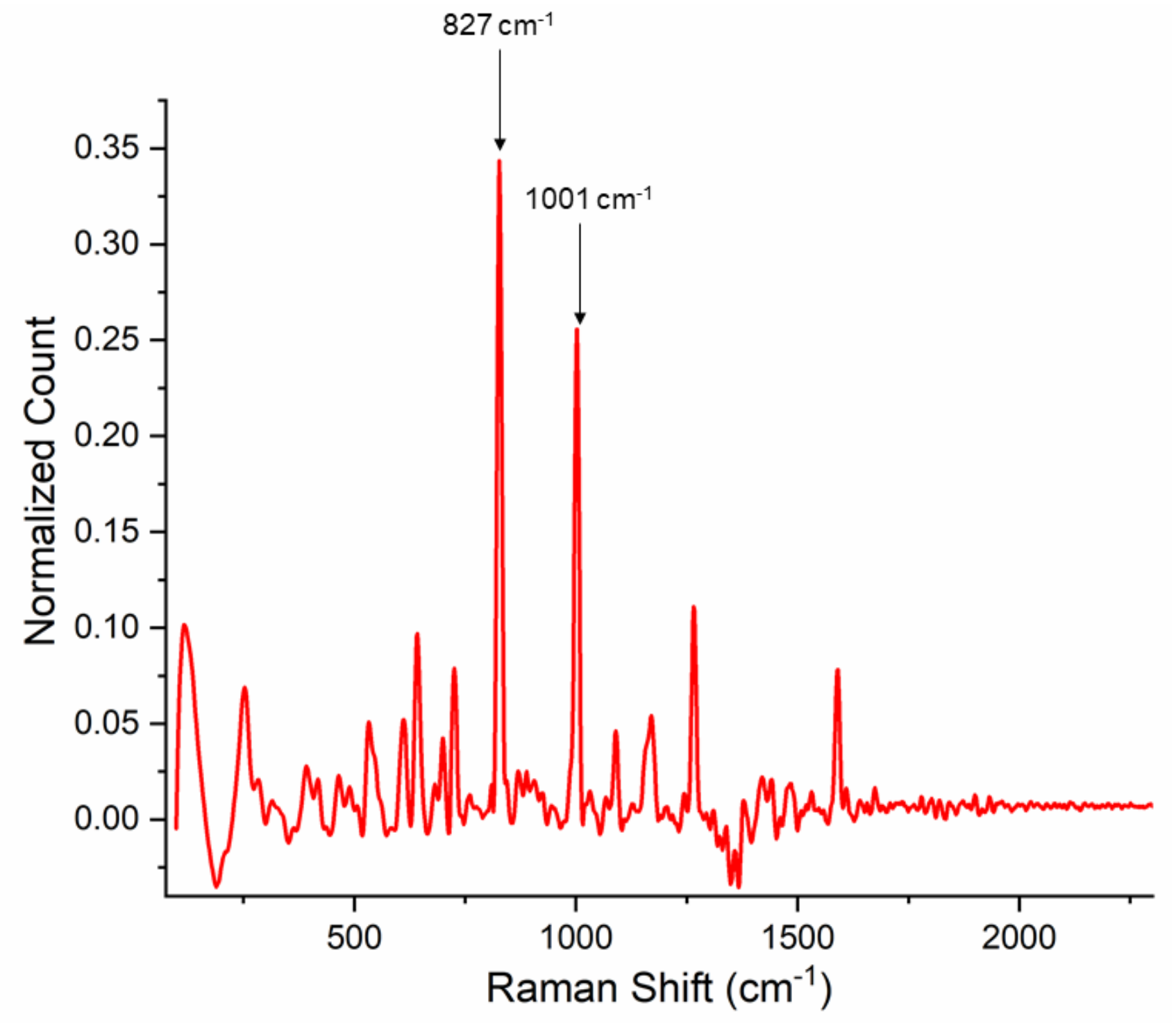

Figure S9. Solid state Raman spectrum for complex 1-CI. 


\section{XRD Data}

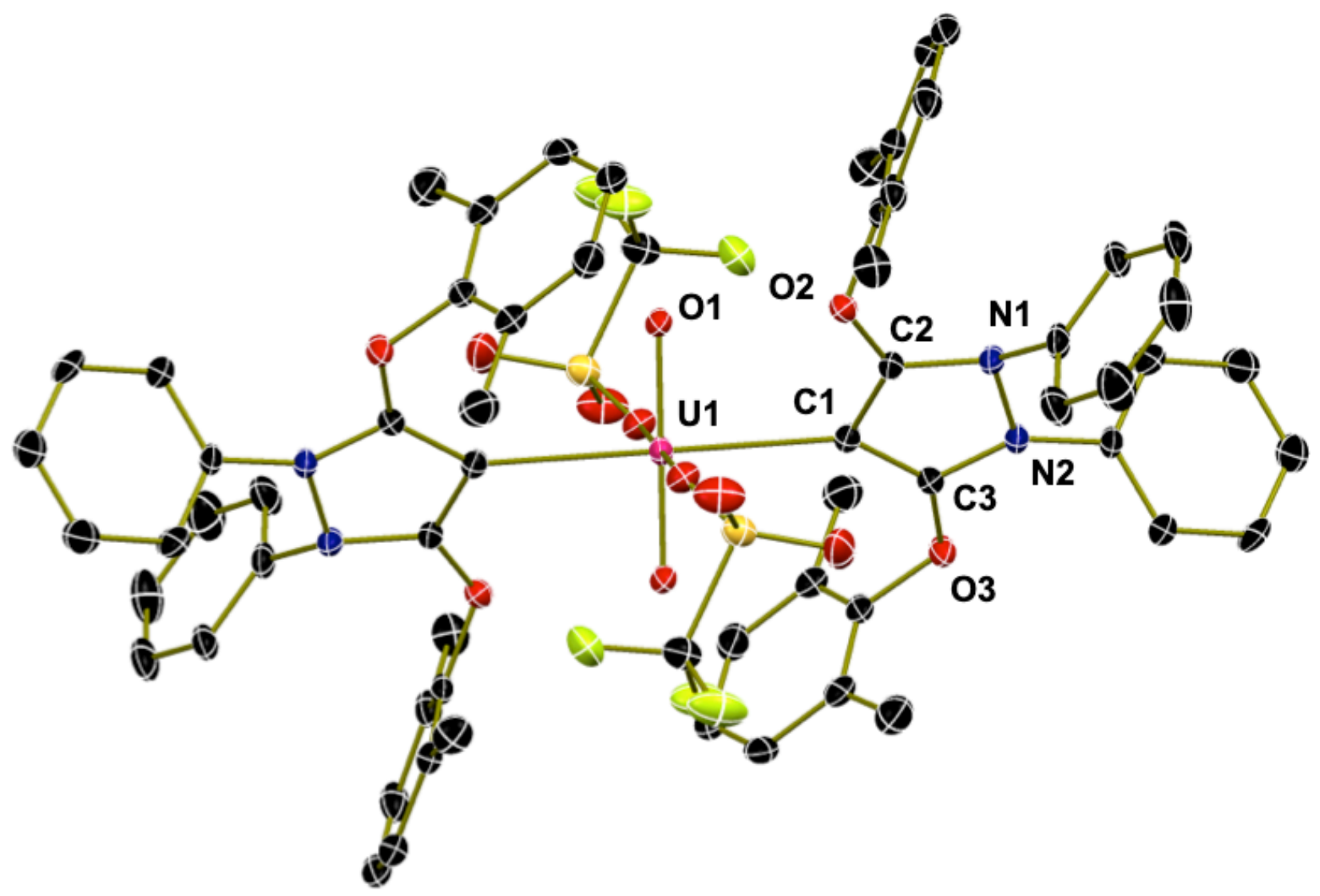

Figure S10. Crystal structure ORTEP diagram of complex 1-OTf. Ellipsoids are shown at $30 \%$ probability level.

Table S1. Crystal, Data Collection and Refinement Parameters for Complex 1-OTf

\section{Crystal data}

Chemical formula

$M_{\mathrm{r}}$

Crystal system, space group

Temperature $(\mathrm{K})$

$a, b, c(\AA)$

$\beta\left(^{\circ}\right)$

$V\left(\AA^{3}\right)$

Z

Radiation type

$\mu\left(\mathrm{mm}^{-1}\right)$

Crystal size $(\mathrm{mm})$

\section{Data collection}

Diffractometer

Absorption correction
$\mathrm{C}_{64} \mathrm{H}_{56} \mathrm{~F}_{6} \mathrm{~N}_{4} \mathrm{O}_{12} \mathrm{~S}_{2} \mathrm{U}$ [+ solvent]

1489.28

Monoclinic, $P 2_{1} / C$

150

11.8826 (8), 18.1970 (12), 16.8346 (12)

$96.962(3)$

$3613.3(4)$

2

Mo Ka

2.38

$0.30 \times 0.20 \times 0.02$

Bruker AXS D8 Quest CMOS diffractometer Multi-scan 


\begin{tabular}{l|l}
$T_{\min }, T_{\max }$ & $0.555,0.746$ \\
\hline $\begin{array}{l}\text { No. of measured, independent and } \\
\text { observed }[I>2 \sigma(I)] \text { reflections }\end{array}$ & $94641,9026,6636$ \\
\hline$R_{\text {int }}$ & 0.062 \\
\hline$(\sin \theta / \lambda)_{\max }\left(\AA^{-1}\right)$ & 0.669 \\
\hline Refinement & \\
$R\left[F^{2}>2 \sigma\left(F^{2}\right)\right], w R\left(F^{2}\right), S$ & $0.042,0.099,1.18$ \\
\hline No. of reflections & 9026 \\
\hline No. of parameters & 407 \\
\hline$H$-atom treatment & $H$-atom parameters constrained \\
$\Delta \rho_{\max }, \Delta \rho_{\min }\left(\mathrm{e} \AA^{-3}\right)$ & $1.41,-1.81$
\end{tabular}

\section{Comments}

The structure contains 2 independent solvent accessible voids of $775 \AA^{3}$ combined. No substantial electron density peaks were found in the solvent accessible voids (less than 2 electron per $\AA^{3}$ ) and the residual electron density peaks are not arranged in an interpretable pattern. The structure factors were instead augmented via reverse Fourier transform methods using the SQUEEZE routine (P. van der Sluis \& A.L. Spek (1990). Acta Cryst. A46, 194-201) as implemented in the program Platon. The resultant FAB file containing the structure factor contribution from the electron content of the void space was used in together with the original hkl file in the further refinement. (The FAB file with details of the Squeeze results is appended to the deposited cif file). The Squeeze procedure corrected for 182 electrons within the solvent accessible voids. 


\section{References:}

1. Pangborn, A. B.; Giardello, M. A.; Grubbs, R. H.; Rosen, R. K.; Timmers, F. J. "Safe and Convenient Procedure for Solvent Purification." Organometallics 1996, 15, 1518-1520.

2. Berthet, J. C.; Lance, M.; Nierlich, M.; Ephritikhine, M. "Simple Preparations of the Anhydrous and Solvent-Free Uranyl and Cerium(IV) Triflates $\mathrm{UO}_{2}(\mathrm{OTf})_{2}$ And Ce(OTf $)_{4}$ - Crystal Structures Of $\mathrm{UO}_{2}(\mathrm{OTf})_{2}(\mathrm{Py})_{3}$ And $\left[\left\{\mathrm{UO}_{2}(\mathrm{Py})_{4}\right\}_{2}(\mu-\mathrm{O})\right][\mathrm{OTf}]_{2}$." Eur. J. Inorg. Chem. 2000, 1969-1973.

3. Arnáiz, F. J.; Pedrosa, M. R.; Aguado, R.; McPherson, L. D.; Béreau, V. M.; Abu-Omar, M. M.; Salzer, A.; Bauer, A.; Geyser, S.; Podewils, F.; Walker, G. W.; Nocera, D. G.; Flamini, A.; Annibale, G.; Pitteri, B.; Kukushkin, V. Y.; Izotova, Y. A.; Tudela, D.; Mendía, A.; Cerrada, E.; Laguna, M.; Reger, D. L.; Collins, J. E.; Wilkerson, M. P.; Burns, C. J.; Paine, R. T. "Organometallic and Coordination Complexes." Inorg. Synth. 2004, 49-95.

4. Fortier, S.; Hayton, T. W. "Oxo Ligand Functionalization in the Uranyl Ion $\left(\mathrm{UO}_{2}{ }^{2+}\right) . "$ Coord. Chem. Rev. 2010, 254, 197-214.

5. Pranckevicius, C. S., D. W. "Three-Coordinate, Cyclic Bent Allene Iron Complexes." Organometallics 2013, 32, 2693-2697.

6. Oldham, S. M.; Scott, B. L.; Oldham Jr, W. J. "Reaction of the N-Heterocyclic Carbene, 1,3-DimesitylImidazol-2-Ylidene, with a Uranyl Triflate Complex, $\mathrm{UO}_{2}(\mathrm{OTf})_{2}(\mathrm{THF})_{3} . "$ Appl. Organomet. Chem. 2006, 20, 39-43.

7. Frisch, M. J.; Trucks, G. W.; Schlegel, H. B.; Scuseria, G. E.; Robb, M. A.; Cheeseman, J. R.; Scalmani, G.; Barone, V.; Mennucci, B.; Petersson, G. A.; Nakatsuji, H.; Caricato, M.; Li, X.; Hratchian, H. P.; Izmaylov, A. F.; Bloino, J.; Zheng, G.; Sonnenberg, J. L.; Hada, M.; Ehara, M.; Toyota, K.; Fukuda, R.; Hasegawa, J.; Ishida, M.; Nakajima, T.; Honda, Y.; Kitao, O.; Nakai, H.; Vreven, T.; Montgomery Jr., J. A.; Peralta, J. E.; Ogliaro, F.; Bearpark, M. J.; Heyd, J.; Brothers, E. N.; Kudin, K. N.; Staroverov, V. N.; Kobayashi, R.; Normand, J.; Raghavachari, K.; Rendell, A. P.; Burant, J. C.; Iyengar, S. S.; Tomasi, J.; Cossi, M.; Rega, N.; Millam, N. J.; Klene, M.; Knox, J. E.; Cross, J. B.; Bakken, V.; Adamo, C.; Jaramillo, J.; Gomperts, R.; Stratmann, R. E.; Yazyev, O.; Austin, A. J.; Cammi, R.; Pomelli, C.; Ochterski, J. W.; Martin, R. L.; Morokuma, K.; Zakrzewski, V. G.; Voth, G. A.; Salvador, P.; Dannenberg, J. J.; Dapprich, S.; Daniels, A. D.; Farkas, Ö.; Foresman, J. B.; Ortiz, J. V.; Cioslowski, J.; Fox, D. J. Gaussian 09, Gaussian, Inc.: Wallingford, CT, USA, 2009.

8. Becke, A. D. "Density-Functional Thermochemistry. III. The Role of Exact Exchange. ." J. Chem. Phys. 1993, 98, 5648-5652.

9. Perdew, J. P.; Chevary, J. A.; Vosko, S. H.; Jackson, K. A.; Pederson, M. R.; Singh, D. J.; Fiolhais, C. "Atoms, Molecules, Solids, and Surfaces: Applications of the Generalized Gradient Approximation for Exchange nd Correlation." Phys. Rev. B 1992, 46, 6671-6687.

10. Grimme, S.; Ehrlich, S.; Goerigk, L. "Effect of the Damping Function in Dispersion Corrected Density Functional Theory." J. Comp. Chem. 2011, 32, 1456-1465.

11. Küchle, W.; Dolg, M.; Stoll, H.; Preuss, H. "Energy-adjusted Pseudopotentials for the Actinides. Parameter Sets and Test Calculations for Thorium and Thorium Monoxide." J. Chem. Phys. 1994, 100, 7535

12. Cao, X.; Dolg, M.; Stoll, H. "Valence Basis Sets For Relativistic Energy-Consistent Small-Core Actinide Pseudopotentials." J. Chem. Phys. 2002, 118, 487-496.

13. Cao, X.; Dolg, M. "Segmented Contraction Scheme for Small-Core Actinide Pseudopotential Basis Sets." J. Mol.Struct. 2004, 673, 203-209.

14. Hariharan, P. C.; Pople, J. A. "The Influence of Polarization Functions on Molecular Orbital Hydrogenation Energies." Theor. Chim. Acta 1973, 28, 213-222.

15. Hehre, W. J.; Ditchfield, R.; Pople, J. A. "Self-Consistent Molecular Orbital Methods. XII. Further Extensions of Gaussian-Type Basis Sets for Use in Molecular Orbital Studies of Organic Molecules." J. Chem. Phys. 1972, 56, 2257-2261.

16. Lu, T.; Chen, F. "Multiwfn: A Multifunctional Wavefunction Analyzer." J. Comp. Chem. 2012, 33, 580-592. 